\title{
An overview of safety effects on pedestrians at modern roundabouts
}

\author{
A. Granà \\ Department of Civil, Environmental and Aerospace Engineering, \\ Palermo University, Italy
}

\begin{abstract}
Pedestrians are important users of the transportation system, but most guidelines have given them little importance in the geometric design of roads and intersections. In these cases it can be difficult for vehicles and pedestrians to share the road safely, particularly at intersections where vehicle-pedestrian conflicts (and the risk of vehicle-pedestrian crashes) can be a frequently recurring situation even with low pedestrian volume. In a sustainable safety vision road system planning and design must include engineering choices that help to improve the sharing of road space between vehicles and pedestrians, as well as for other vulnerable users. It is known that modern roundabouts are safer than other intersection forms both for effects on speeds and for effects on conflicts between road users; several road authorities, indeed, have foreseen to convert specific types of intersections into roundabouts. Summarizing international experience with roundabouts and pedestrians, the paper provides a review of the existing literature dealing with pedestrian safety and accessibility issues at roundabouts. First, safety aspects at modern roundabouts are presented, followed by a brief explanation of the effects of roundabouts on pedestrian safety documented in the scientific literature. At last, this research provides an overview of the current state of practice and implications in the roundabout design to maximize their potential with regard to safety pedestrians.

Keywords: road safety, pedestrian safety, roundabout.
\end{abstract}

\section{Introduction}

Modern roundabouts are circular intersection in which vehicles circulate anticlockwise the circulatory roadway installed around a central island and have 
the right-of-way. Entering vehicles, in turn, yield at the edge of the circulating roadway until a gap in the circulating traffic flow becomes available. At approaches entering and exiting lanes are separated by (raised or painted) splitter islands. The use of raised splitter islands, as well as roadway alignment, deflect vehicles into a proper entry path avoiding entry tangential to the circular roadway and forcing drivers to reduce speeds as they proceed into and through the intersection. This ensures consistency between speeds of vehicles circulating and vehicles entering the roundabouts, as well as lower speed differentials with other road users. Moreover, the use of splitter islands also provide a refuge for pedestrians which allows them to cross the street in two stages [1]. Figure 1 shows geometric design elements of a modern roundabout.

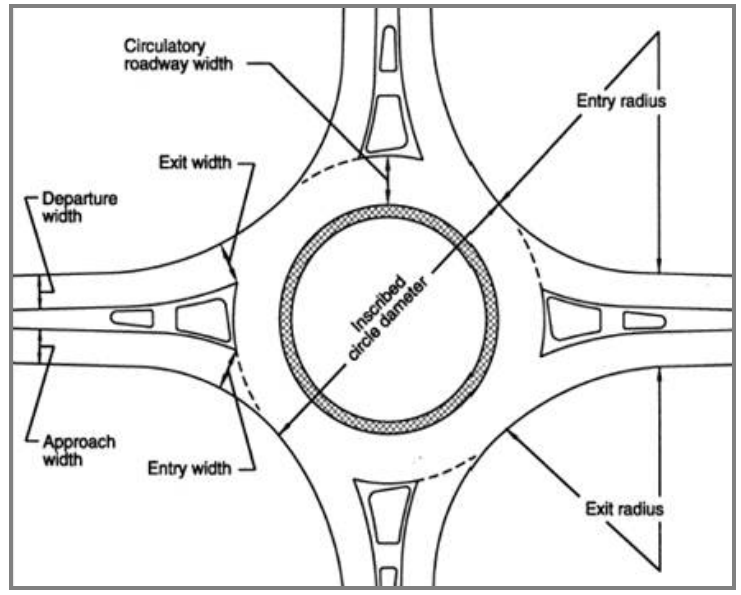

Figure 1: Geometric design elements for roundabouts [roundabouts: An informational guide, publication number: FHWA-RD-00-068 /2000].

Roundabouts can be separated into basic categories by size of the inscribed circle diameter $\left(\mathrm{D}_{\mathrm{i}}\right)$ : large roundabouts, conventional roundabouts, miniroundabouts. Some fundamental design elements for each roundabout category, as referred in [2], are summarized in Table 1.

A modern roundabout, properly designed and installed at appropriate locations, has the potential to generate several advantages over other types of atgrade intersections in safety, capacity, environmental, economic and esthetic considerations; nevertheless, there are conditions under which roundabouts are not suitable either for new installations or for replacing an existing intersection with a roundabout $[3,4]$.

Many studies have proven that one of the main benefits of roundabout installations is the improvement in intersection safety performance than other intersection forms. Roundabouts slow all vehicles allowing drivers more time to react to potential conflicts (also helping to reduce crash severity) and provide refuges for pedestrians to cross a traffic stream at a time. The physical guidance 
and the separation of the various movements by the splitter islands and the central island reduce the number of conflict points. Roundabouts create 75 per cent fewer opportunities for vehicle to vehicle conflicts, having only 8 vehicle to vehicle conflict points and 8 vehicle to pedestrian conflict points whereas a typical four-way intersection has a total of 32 vehicle to vehicle conflict points and 24 vehicle to pedestrian conflict points. Also none of these conflict points at roundabouts are at right angles; at traditional intersections, right angle crashes, indeed, are the most severe crashes that can produce an injury or fatality.

Table 1: $\quad$ Design elements for roundabouts [2].

\begin{tabular}{|c|c|c|c|c|c|}
\hline \multirow{2}{*}{$\begin{array}{l}\text { Roundabout } \\
\text { category } \\
\mathrm{D}_{\mathrm{i}}[\mathrm{m}]\end{array}$} & \multicolumn{2}{|c|}{ Circular roadway } & \multicolumn{2}{|c|}{ Entry arms } & \multirow[b]{2}{*}{ Exit [m] } \\
\hline & $\begin{array}{l}\text { one-lane } \\
\text { entry }[\mathrm{m}]\end{array}$ & $\begin{array}{l}\text { two-lane } \\
\text { entry }[\mathrm{m}]\end{array}$ & $\begin{array}{l}\text { one-lane } \\
\text { entry }[\mathrm{m}]\end{array}$ & $\begin{array}{l}\text { two-lane } \\
\text { entry }[\mathrm{m}]\end{array}$ & \\
\hline Large: $\mathrm{D}_{\mathrm{i}}>50$ & 6 & 9 & 3,5 & 6 & 4,5 \\
\hline $\begin{array}{c}\text { Conventional } \\
40 \leq \mathrm{D}_{\mathrm{i}} \leq 50\end{array}$ & 6 & 9 & 3,5 & 6 & 4,5 \\
\hline $\begin{array}{c}\text { Compact } \\
25 \leq \mathrm{D}_{\mathrm{i}}<40\end{array}$ & 7 & $8,5-9$ & 3,5 & 6 & 4,5 \\
\hline $\begin{array}{c}\text { Mini } \\
14 \leq \mathrm{D}_{\mathrm{i}}<25\end{array}$ & $7-8$ & $8,5-9$ & 3,5 & 6 & 4 \\
\hline
\end{tabular}

Central island treatments can be: i) partially traversable to help trucks at mini-roundabouts with an inscribed diameter between $18 \mathrm{~m}$ and $25 \mathrm{~m}$; ii) fully traversable at mini-roundabouts with an outer diameter between 14 - $18 \mathrm{~m}$. Compact roundabouts are characterized by a central island with non-surmountable kerbs.

Roundabouts have been found to lower number and severity of crashes as compared to traditional forms of intersection design and traffic control due to the reduction of vehicular conflict points (as well as lower speeds) and of overall crash frequencies for a wide range of urban, suburban, and rural settings [5-13]. Experience has shown that entry geometry plays an important role in determining most probable crash types: an entry tangential to the circulating vehicle path can be the cause of entry-circulating collisions because these drivers will be less inclined to yield; conversely, an entry almost perpendicular to the circulating vehicle path can generate rear-end and loss of control collisions because abrupt braking may be necessary. An intermediate situation for entry geometry can be most appropriate depending on antagonist traffic volumes and site characteristics. It must be said that crash reductions are most pronounced for motor vehicle, less pronounced for pedestrians (30-40 per cent reduction), bicyclists (10 per cent) and motorcyclists depending on the study and design treatments $[6,10,14,15]$; moreover, the safety benefit is greater for small- and medium-capacity roundabouts than for large or multilane roundabouts $[5,6,16]$. Evaluation studies based on crash data, traffic data and geometric data also showed variation in crash rates at roundabouts, or particular groups of roundabouts, mainly driven by the traffic exposure [17]. The results of statistical crash data analysis in different countries where the roundabouts are in operation 
by time, particularized for individual crash categories, are reported in several studies to which it refers. Only for illustrative purposes, Figure 2 shows a comparison of disaggregated crash data in the U.S.A. and UK databases $[5,16]$.

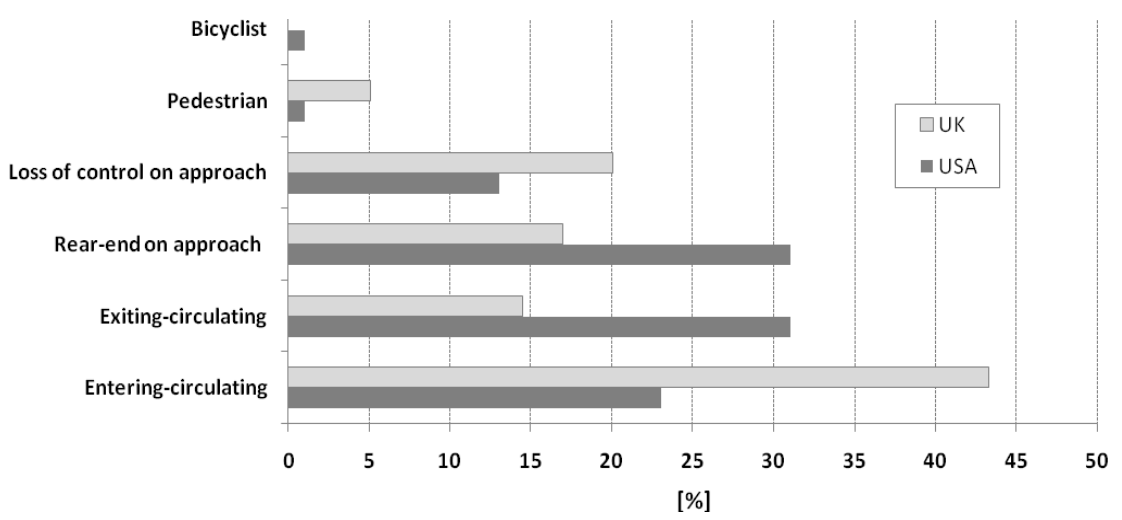

Figure 2: Disaggregated crash data in UK and USA $[5,16]$.

A better understanding of effects on the safety by the various geometric design elements and traffic exposure can assist the designer in optimizing the safety of all users. According to [5, 8, 16-20], Table 2 summarizes measures with a significant relationship with crash frequency at roundabouts for some crash categories: single vehicle (sv); crash between an entering and a circulating

Table 2: $\quad$ Measures affecting road safety at roundabouts.

\begin{tabular}{|c|c|c|c|c|c|}
\hline \multirow{2}{*}{ Measure } & \multicolumn{5}{|c|}{ Crash category } \\
\hline & SV & $\mathrm{e} / \mathrm{c}$ & re & $\mathrm{p}$ & exit/c \\
\hline \multicolumn{6}{|l|}{ AADT } \\
\hline \multicolumn{6}{|l|}{ Pedestrian volumes } \\
\hline \multicolumn{6}{|l|}{ Number of approaching lanes } \\
\hline \multicolumn{6}{|l|}{ Number of circulating lanes } \\
\hline \multicolumn{6}{|l|}{ Radius of vehicle path } \\
\hline \multicolumn{6}{|l|}{ entry deflection } \\
\hline \multicolumn{6}{|l|}{ Percentage of motorcycles } \\
\hline \multicolumn{6}{|l|}{ Angle to next approach } \\
\hline \multicolumn{6}{|l|}{ Sight distance } \\
\hline $\begin{array}{l}\text { Weaving length between splitter } \\
\text { islands }\end{array}$ & & & & $* *$ & \\
\hline Distance to first sight of roundabout & & & & $* *$ & \\
\hline \multicolumn{6}{|l|}{ Length of vehicle path } \\
\hline \multicolumn{6}{|l|}{$85^{\text {th }}$ percentile speeds } \\
\hline \multicolumn{6}{|l|}{ Reduction in $85^{\text {th }}$ percentile speed } \\
\hline Posted speed limit & & & & $* *$ & \\
\hline
\end{tabular}


vehicle (e/c); rear-end crash on the approach (re); pedestrian (p); crash between an exiting and a circulating vehicle at multilane roundabouts (exit/c). In particular, the entry deflection forces all vehicles to slow down, reducing the probability of a crash and the severity of a crash (see Figure 3).
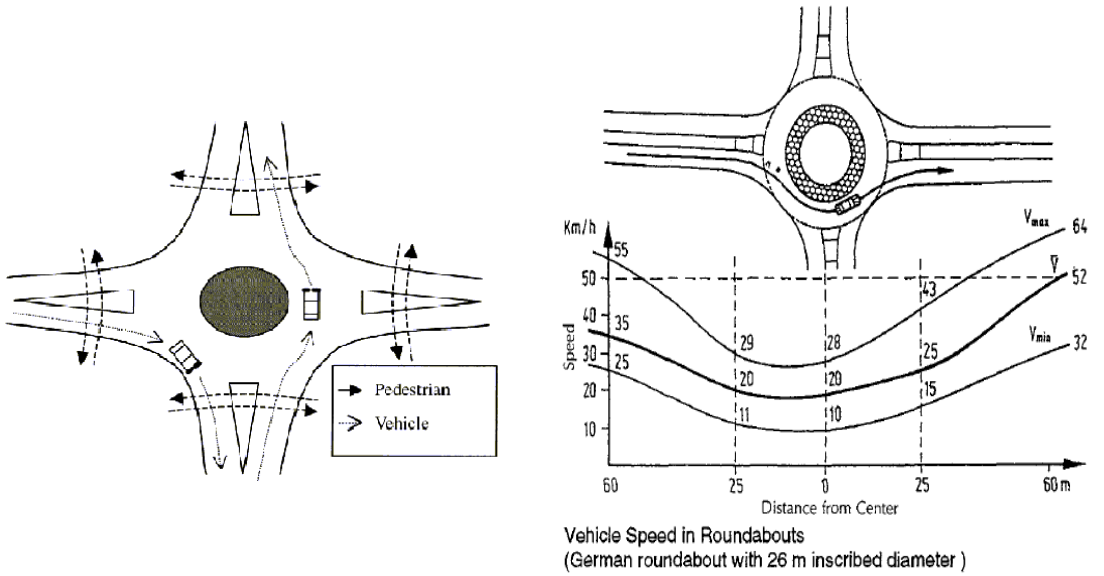

Figure 3: $\quad$ Factors affecting safety at roundabouts.

Several efforts have been taken to evaluate crash reductions at roundabouts compared to other intersection types. A review of international experience and evaluation studies on safety performances at existing roundabouts is shown in Table 3. Understanding the relationships between roundabout design features and crash frequency through the use of safety models can facilitate design of roundabouts by quantifying the safety implications of design decisions and by determining the effectiveness of roundabouts as a treatment for intersecting roadways. A comprehensive review of safety models is included in NCHRP Report 572 on roundabouts in the United States (on line from 2007). The same report presents an overview of safety prediction models developed for intersection-level and approach-level analyses. The intersection level models were developed for total and injury collisions; the approach-level models were developed for all severities combined for several collision types: entering/circulating, exiting/circulating, and approaching. These models are suitable for eventual inclusion in the second edition of Highway Safety Manual crash prediction procedures [13].

Starting from these considerations on safety issues at roundabouts, the paper summarizes the international experiences with roundabouts and pedestrians trying to focus on effects of roundabouts on pedestrian safety. At last, this research provides an overview of the current state of practice and implications documented in the scientific literature in the roundabout design to maximize their potential with regard to safety for pedestrians. 
Table 3: $\quad$ Summary of safety studies at roundabouts.

\begin{tabular}{|c|c|c|c|}
\hline Author and country & $\begin{array}{c}\text { Sample } \\
\text { size }\end{array}$ & Type of study & Findings \\
\hline $\begin{array}{c}\text { Austroads, 1993, } \\
\text { Australia [21] }\end{array}$ & 73 & Before-and-after & $\begin{array}{l}\text { Crash reduction after roundabout installed*: } \\
-\quad 74 \% \text { in the casualty crash rate } \\
-\quad 32 \% \text { in property damage only } \\
-\quad 68 \% \text { in pedestrian casualty crashes per } \\
\text { year. } \\
\text { *control before roundabout: give way to the } \\
\text { right - stop - give way }\end{array}$ \\
\hline $\begin{array}{l}\text { Giaever, 1992, } \\
\text { Norway [22] }\end{array}$ & 59 & $\begin{array}{l}\text { Comparison with } \\
124 \text { signalized } \\
\text { intersections }\end{array}$ & $\begin{array}{l}\text { - } 3 \text {-arm intersections: } 0,03 \text { crash rate at } \\
\text { roundabouts vs } 0,05 \text { crash rate at signalized } \\
\text { intersections; } \\
\text { - } 4 \text {-arm intersections: } 0,05 \text { crash rate at } \\
\text { roundabouts vs } 0,1 \text { crash rate at signalized } \\
\text { intersections; } \\
-1 \text { pedestrian crash at roundabout vs } 20 \% \text { of } \\
\text { injury crashes at signalized intersections; } \\
-36 \% \text { of two-wheeled vehicles at } \\
\text { roundabouts vs } 23 \% \text { at signalized } \\
\text { intersections }\end{array}$ \\
\hline $\begin{array}{l}\text { Schoon and Van } \\
\text { Minnen, 1993, the } \\
\text { Netherlands [23] }\end{array}$ & 181 & $\begin{array}{l}\text { Before-and-after } \\
\text { without control } \\
\text { (mostly single- } \\
\text { lane } \\
\text { roundabouts) }\end{array}$ & $\begin{array}{l}\text { crash reduction at roundabouts: } \\
-\quad 73 \% \text { in all pedestrian injury crashes } \\
-\quad 89 \% \text { for pedestrian fatality; } \\
-\quad 63 \% \text { for moped injuries; } \\
-\quad 30 \% \text { for cycle injuries. }\end{array}$ \\
\hline $\begin{array}{l}\text { Brilon W. et al., } \\
\text { 1993, Germany } \\
\text { [24] }\end{array}$ & 25 & $\begin{array}{l}\text { Before-and-after } \\
\text { (with data on } \\
\text { traffic volume } \\
\text { before and after) }\end{array}$ & $\begin{array}{l}- \text { a } 75 \% \text { decrease in average vehicle } \\
\text { pedestrian crashes for } 25 \text { intersections } \\
\text { converted from stop signs or traffic signals } \\
\text { to roundabouts. }\end{array}$ \\
\hline $\begin{array}{l}\text { Guichet, 1997, } \\
\text { France [25] }\end{array}$ & 12.000 & $\begin{array}{l}\text { Comparisons } \\
\text { with rural } \\
\text { intersections } \\
\text { traditionally } \\
\text { controlled and } \\
\text { roundabouts with } \\
\text { similar traffic } \\
\text { flows }\end{array}$ & $\begin{array}{l}\text { - } \text { less than } 25 \% \text { of serious injury crashes or } \\
\text { fatalities at roundabouts; } \\
\text { - } 38 \text { fatal or serious type injuries for every } \\
100 \text { crashes at roundabouts vs } 55 \text { injury or } \\
\text { fatal crashes for every } 100 \text { crashes at } \\
\text { controlled intersections; } \\
\text { - crash frequencies } 4 \text { times higher at } \\
\text { signalized intersections than roundabouts. }\end{array}$ \\
\hline $\begin{array}{l}\text { Persaud B. et al., } \\
2001 \text {, USA. [10] }\end{array}$ & 23 & $\begin{array}{l}\text { before-after } \\
\text { study } \\
\text { (conversion of } 23 \\
\text { intersections } \\
\text { from stop sign } \\
\text { and traffic signal } \\
\text { control to } \\
\text { roundabouts) }\end{array}$ & $\begin{array}{l}\text { - } \quad 90 \% \text { reduction in fatal crashes; } \\
-\quad 76 \% \text { reduction in injury crashes; } \\
-\quad 30-40 \% \text { reduction in pedestrian crashes; } \\
-\quad 10 \% \text { in bicycle crashes. }\end{array}$ \\
\hline $\begin{array}{l}\text { Elvik, R., } \\
2003 \text { [24] }\end{array}$ & - & $\begin{array}{l}\text { meta-analysis of } \\
\text { studies } \\
\text { ( } 28 \text { studies } \\
\text { reported outside } \\
\text { the United States } \\
\text { to obtain } \\
\text { estimates of } \\
\text { effect on road } \\
\text { safety of } \\
\text { converting } \\
\text { intersections to } \\
\text { roundabouts) } \\
\end{array}$ & $\begin{array}{l}-\quad \text { a } 30 \% \text { to } 50 \% \text { reduction in the number of } \\
\text { injury accidents; } \\
\text { - } \quad \text { a } 50 \% \text { to } 70 \% \text { reduction in the number of } \\
\text { fatal accidents; } \\
\text { - } \quad \text { the roundabout effect on injury accidents } \\
\text { is greater in } 4-\text { leg intersections than in 3- } \\
\text { leg intersections; } \\
\text { - } \\
\text { the roundabout effect is greater in } \\
\text { intersections previously controlled by } \\
\text { yield signs than in intersections } \\
\text { previously controlled by traffic signals. }\end{array}$ \\
\hline
\end{tabular}




\section{Effects of roundabouts on pedestrian safety}

Several surveys and studies undertaken to explain the reduction of vehicular crashes at roundabouts highlighted that safety benefits at roundabouts are mainly due to slow speeds and to fewer potential vehicle-pedestrian conflict points compared to other intersection forms. Pedestrian injury statistics supported by documentary evidence indicate a favourable trend regarding pedestrian safety, but no statistically significant conclusions can be drawn [10]. On the contrary, as already anticipated in the previous paragraph, European safety studies provide significant results regarding pedestrian safety. In Sweden a 2000 study of vehicle-pedestrian crash data from 72 roundabouts (as compared with expected values for comparable intersections with signals, controlling for pedestrian volumes and traffic flow) showed that single-lane roundabouts are very safe for pedestrian compared to conventional or signal controlled intersections (about a $78 \%$ reduction in injuries) and that multi-lane roundabouts are about as safe as other intersections [26]. A synthesis of roundabout advantages and disadvantages for pedestrians are shown in Table 4.

Table 4: $\quad$ Roundabout advantages and disadvantages for pedestrians [27, 28].

\begin{tabular}{|c|c|}
\hline Advantages & Disadvantages \\
\hline $\begin{array}{l}\text { - Traffic speeds are generally lower than } \\
\text { other intersections, meaning less chance of } \\
\text { injury in a collision. }\end{array}$ & $\begin{array}{l}\text { - Entering traffic does not necessarily stop } \\
\text { causing hesitation by pedestrians in the } \\
\text { crosswalk. }\end{array}$ \\
\hline $\begin{array}{l}\text { - Drivers are more likely to see pedestrians } \\
\text { in the crosswalk. }\end{array}$ & $\begin{array}{l}\text { - Anxiety in pedestrians who are not confident } \\
\text { judging gaps in traffic }\end{array}$ \\
\hline $\begin{array}{l}\text { - Crossing distances are usually shorter due } \\
\text { to splitter islands, allowing one to focus } \\
\text { on one direction of traffic at a time. }\end{array}$ & $\begin{array}{l}\text { - Crossing locations and set backs from the } \\
\text { yield line often raise travel distances for } \\
\text { pedestrians. }\end{array}$ \\
\hline $\begin{array}{l}\text { - Perceived risks are higher than real risks } \\
\text { due to the absence of an exchange of the } \\
\text { right-of-way priority by the traffic signals. }\end{array}$ & $\begin{array}{l}\text { - The accommodation of visually impaired } \\
\text { pedestrians is a challenge where roundabouts } \\
\text { are not yet widely used. }\end{array}$ \\
\hline
\end{tabular}

It should be added that roundabouts can be perceived as unsafe by pedestrians [29], but, at roundabouts crash risks from left-turning vehicles crossing the intersection during the same phase as the pedestrian crossing fail [30]; moreover, less wait time accomplishes pedestrian crossing movement than at conventional intersections with many protected phases [27].

The reduced traffic speed, the simplification of conflicts, the minimization of the conflict area between pedestrians and vehicles are three reasons generally cited to maximize safety for pedestrians at roundabouts [29]. Certain design features, as well as different engineering modifications to the built environment, were found to be important to reduce risks of pedestrian injuries and fatalities [31]. Although it is undeniable the effect of the geometric design of the intersection on safety performance, as well as on operations, there is no consensus internationally about the specific effect of individual geometric elements on safety and operational performances; nevertheless, it is generally shared the need to combine certain basic principles within the roundabout design [32]. 
Starting on the above considerations on safety issues related to pedestrians at roundabouts, in the next paragraph considerations on practices and implications in the roundabout design to maximize their potential with regard to safety pedestrians are provided.

\section{Geometric design implications to maximize pedestrians safety at roundabouts}

Traffic engineering design can apply now a wide array of measures developed to assist pedestrians and to minimize the risk and severity of vehicle-pedestrian crashes. Researches and studies examined under this literature review on the specific topic suggest that sharing of road space between pedestrians and vehicles can be difficult when road geometric design and built environment assign low priority to pedestrians [33]. A pedestrian casualty study in Australia also reports several design recommendations for pedestrian safety [34], such as ensuring convenient vehicle speed reduction before pedestrian crossings, positioning pedestrian crossings at a distance from the stop line equal to one-totwo car lengths so drivers can encounter separately pedestrian and vehicle conflicts, assuring visibility for pedestrians to see vehicles from all crossing points and for drivers to see all crossing points from each approach, using physical measures to discourage improper pedestrian movements and direct pedestrian to crosswalks.

According to Retting et al. [33], traffic engineering countermeasures can be designed both to manage vehicle speeds and to separate pedestrians and vehicles by time and space, as well as to increase the visibility of pedestrians. A summary of current design features designed to promote pedestrian safety at modern roundabouts are reported in Table 5.

Although current design practices for pedestrians, treatments and methodology for selecting treatments at roundabouts generally appear to be appropriate, the use of measures specifically designed to separate pedestrians and vehicles by time is often site dependent [33]. Recent and ongoing researches suggest that these measures should be evaluated principally in terms of effects on crashes. Nevertheless, many studies on safety effectiveness of road engineering measures result limited by a methodological point of view due to failure to account for regression to the mean resulting in overestimation of the effects of an intervention when high-crash locations are selected to be treated [33]. Some observational road safety studies consider pedestrian-motor vehicle conflicts to value roadway countermeasures, because conflict studies can also provide information about crash causes. Traffic conflicts on the basis of empirical evidence was examined and validated by Hauer and Garder [38]. In any case, given the very large number of roads and the meagre resources available for road engineering countermeasures, these with the greatest potential for crash reduction should have priority. Further research is also needed to develop appropriate treatments to accommodate pedestrians with vision disabilities at modern roundabouts [1]. 
Table 5: $\quad$ Current design practices for pedestrians at roundabouts.

\begin{tabular}{|c|c|}
\hline Measure & Design element \\
\hline Managing speed & $\begin{array}{l}\text { entry and exit } \\
\text { - Another purpose is to maximize visibility of the central island: } \\
\text { - entry curve radii is recommended to be } 10-15 \mathrm{~m}[25] \text {; } \\
\text { - exit curve radii is recommended to be } 10-14 \mathrm{~m}[20] \text {; } \\
\text { - high-speed tangential exit are avoided. }\end{array}$ \\
\hline $\begin{array}{l}\text { Separating } \\
\text { pedestrians and } \\
\text { vehicle by time }\end{array}$ & $\begin{array}{l}\text { installation of traffic signal } \\
\text { Pedestrian activated or regular signals with exclusive pedestrian phases can be } \\
\text { installed at least } 20 \mathrm{~m} \text { away from the circle and signal phasing has to be set so } \\
\text { that vehicles do not back into the roundabout. }\end{array}$ \\
\hline $\begin{array}{c}\text { Separating } \\
\text { pedestrians and } \\
\text { vehicle by space }\end{array}$ & $\begin{array}{l}\text { splitter island } \\
- \text { it acts as a pedestrian refuge island; } \\
\text { - it is recommended to be } 1.6 \text { to } 25 \mathrm{~m} \text { wide [35] or } 3.0 \mathrm{~m} \mathrm{[36].}\end{array}$ \\
\hline $\begin{array}{l}\text { Increasing } \\
\text { pedestrian } \\
\text { visibility }\end{array}$ & $\begin{array}{l}\text { pedestrian crossing } \underline{\text { ped }} \\
\text { - provision of pedestrian high-visibility or zebra-striped crossings are } \\
\text { recommended when pedestrian flows reach a certain minimum or } \\
\text { depending on the vehicle/pedestrian conflict }[35,36] \text {. } \\
\text { - location of pedestrian crossing generally recommended is about } 5 \text { to } 6 \mathrm{~m} \\
\text { back from the stop line, because pedestrian crossings close to the circle may } \\
\text { reduce roundabout capacity (potentially longer waiting times at the } \\
\text { entrance) and further away may increase walking distances exposing } \\
\text { pedestrians to higher speeds [29]; } \\
\text { - when entries are flared pedestrian crossing before the flaring [37]. }\end{array}$ \\
\hline
\end{tabular}

\section{Conclusions}

In a sustainable safety vision road system planning and design must include engineering choices that help to improve the sharing of road space between vehicles and pedestrians, as well as other vulnerable users. In this view modern roundabouts represent a very safe solution compared with other types of intersections both for effects on speeds and for effects on conflicts between road users. Starting from a brief examination of the international experience on safety at modern roundabouts, as documented in the scientific literature, the paper focuses on the effects of roundabouts on pedestrian safety. This research also provides an overview of the current state of practice and implications in the roundabout design to maximize the potential with regard to safety pedestrians, highlighting that in the case of many traffic engineering measures more definitive research is needed to establish their effects on pedestrian-vehicle crash risks.

\section{References}

[1] Wadhwa, Lal C., Roundabouts and pedestrians with visual disabilities: How Can We Make Them Safer? 82 ${ }^{\text {nd }}$ TRB Annual Meeting, 12-16 January 2003, Washington DC, USA.

[2] Infrastructure and Transport Ministry. Geometric and functional standards for the construction of intersections. Decree April 19, 2006. 
[3] Isaacs., B. and Barrett J.P. Use Of Roundabouts in an Urban Setting. $2^{\text {nd }}$ Urban Street Symposium (Anaheim, California, USA). July 28-30, 2003.

[4] Lenters, M. Roundabout planning and design for efficiency and safety case study. 2003 Annual Conference of the Transportation Association of Canada, St. John's, Newfoundland \& Labrador, September 2003, pp. 1-21.

[5] Maycock, G. and Hall, R.D. Accidents at 4-Arm Roundabouts, Laboratory Report LR1120, Transportation and Research Laboratory, Crawthorne, Berkshire, U.K. 1984.

[6] Alphand, F., Noelle U., and Guichet B., Roundabouts and Road Safety. State of the Art in France, Intersections without Traffic Signals II, SpringerVerlag, Werner Brilon (Ed.). pp. 107-125, 1991.

[7] Safety of Roundabouts in Urban and Suburban Areas. Centre d'Etude des Transports Urbains, Paris, 1992.

[8] Arndt, O.K., Relationship between roundabout geometry and accident rates. Final Report. Infrastructure design. Transport Technology Division. Department of Main Roads, Brisbane, Queensland, Australia, 1998.

[9] Flannery, A., and Datta, T. K., Modern Roundabouts and Traffic Crash Experience in the United States. Transportation Research Record, vol. 1553, pp. 103-109,1996.

[10] Persaud, B.N., Retting, R.A., Garder, P.E., and Lord D., Safety effect of roundabout conversions in the United States: empirical Bayes observational before-after study. Transportation Research Record, vol. 1751, pp. 1-8, 2001.

[11] De Brabander B, Nuyts E, and Vereeck L., Road safety effects of roundabouts in Flanders. Journal of Safety Research, vol. 36, issue 3, pp.289-96, 2005.

[12] Isebrands H., Crash analysis of roundabouts and high-speed rural intersections. Transportation Research Record, vol. 2096, pp. 1-7, 2009.

[13] Roundabouts: An Informational Guide Second Edition. NCHRP Report 672, 2010 National Academy of Sciences, Transportation Research Board Washington, D.C. 2010, USA.

[14] Schoon, C. C. and van J. Minnen, Accidents on Roundabouts: II. Second Study into the Road Hazard Presented by Roundabouts, Particularly with Regard to Cyclists and Moped Riders. R-93-16. SWOV Institute for Road Safety Research in the Netherlands, 1993.

[15] Brown, M., TRL State of the Art Review: The Design of Roundabouts. London, HMSO, 1995.

[16] Rodegerdts, L., Blogg, M., Wemple, E., Myers, E., Kyte, M., Dixon, M., List, G., Flannery, A., Troutbeck, R., Brilon, W., Wu, N., Persaud, B., Lyon, C., Harkey, D. and Carter. D., NCHRP Report 572: Roundabouts in the United States. Transportation Research Board of the National Academies, Washington, D.C., USA, 2007.

[17] Russell, E. R., and Mandavilli, S., Can modern roundabouts safely accommodate all users? ITE 2004 Annual Meeting, Lake Buena Vista, Florida, August 2004. 
[18] Daniels S, Brijs T, Nuyts E, Wets G., Explaining variation in safety performance of roundabouts. Accident Analysis and Prevention, vol. 42, issue 2, pp. 393-402, 2010.

[19] Brüde, U., and J. Larsson, What Roundabout Design Provides the Highest Possible Safety? Nordic Road and Transport Research, No. 2. Swedish National Road and Transport Research Institute, 2000.

[20] Kleine Kreisverkehre: Empfehlungen zum Einsatz und zur Gestaltung, Bausteine No. 16. Ministerium fur Stadtentwicklung und Verkehr des Landes Nordrhein-Westfalen, 1993.

[21] Roundabouts-Guide to Traffic Engineering and Practice, Austroads, Sydney, Australia, 1993.

[22] Giaever, T., Application, Design and Safety of Roundabout in Norway, The Foundation for Scientific and Industrial Research at the Norwegian Institute of Technology, Norway. Actes du Seminaire Giratoires 92, Nantes, France, October, 1992.

[23] Schoon, C. C. and van Minnen, J., The Safety of Roundabouts in the Netherlands, SWOV Institute for Road Safety Research, Summary Article on Report R-93-16, Leidschendam, The Netherlands, 1993.

[24] Brilon, W. B. Stuwe and O. Drews vas (1993 Report in German) summarized by R. Elvik, Effects on Road Safety of Converting Intersections to Roundabouts, A Review of Evidence From Non-U.S. Studies, Transportation Research Record, Vol. 1847, Transportation Research Board, 2003, pp. 1-10.

[25] Guichet, B., Roundabouts in France: Development, Safety, Design and Capacity, Proceedings of Third International Symposium on Intersections Without Traffic Signals, Portland, Oregon, July 1997, pp. 100-105.

[26] Swedish National Road and Transport Research Institute (VTI), What Roundabout Design Provides the Highest Possible Safety, Nordic Road and Transport Research, vol. 2, pp. 17-21, 2000.

[27] Furtado G., Accomodating vulnerable road users in roundabout design. 2004 Annual conference of the transportation of Canada, Quebec City, Quebec, Canada.

[28] Weber P., Roundabout safety experience. Paper prepared for presentation at the Road Safety / Geometric Design Session of the 2007 Annual Conference of the Transportation Association of Canada, Saskatoon, Saskatchewan. (Chapter 5 of the Synthesis of North American Roundabout Practice).

[29] Jacquemart, G. et al., Modern Roundabout Practice in the United States. NCHRP Synthesis 264. Transportation Research Board National academy press, Washington, D.C. USA, 1998.

[30] Habib, P.A., Pedestrian Safety: The Hazards of Left-Turning Vehicles. ITE Journal, Institute of Transportation Engineers, April 1980, pp. 33-37.

[31] Conception des Carrefours a sens Giratoire Implantes en Milieu Urbain, Centre d'Etudes des Transports Urbains (CETUR), Ministere de l'Equipement, du Logement, de l'Amenagement du Territoire et des Transports, 1988. 
[32] Rodegerdts, L. A., State-of-the-Art in U.S. Roundabout Practice. 2005 Annual Meeting of Institute of Transportation Engineering, Melbourne, Australia, 2005.

[33] Retting, R. A., Ferguson, S. A. and McCartt, A. T., A review of evidencebased traffic engineering measures designed to reduce pedestrian-motor vehicle crashes. American Journal of Public Health. Vol. 93, n.9, pp. 1456-1463, 2003.

[34] Tumber, C., Review of Pedestrian Safety at Roundabouts, Vic Roads, Road Safety Department, Melbourne, AU, 1997.

[35] Brilon, W., Sicherheit von Kreisverkehrsplatzen, unpublished paper (1996).

[36] Ourston \& Doctors, Roundabout Design Guidelines, California, 1995, pp. 50.

[37] Geometric Design of Roundabouts, Design Manual for Roads and Bridges, Vol. 6, Section 2, Part 3, TD 16/93, United Kingdom, 1993.

[38] Hauer E. and Garder P., Research into the validity of the traffic conflicts technique. Accid Anal Prev. 1986; vol. 18, pp. 471-481. 